\title{
ICRC action during the Second World War
}

Following allegations that appeared in the press last summer, calling into question the actions of some of its delegates during the Second World War, the ICRC resolved to shed full light on that period in its history. The allegations were based on a number of reports by agents of the US Office of Strategic Services (OSS), the predecessor of today's CIA, and suggested that ICRC delegates had been involved in activities that were inconsistent with the organization's humanitarian mandate.

Having made a thorough search of its own archives and those of the Swiss Confederation, the ICRC can now firmly state that, among the 49 people whose names are quoted in the OSS documents, only 18 worked for the organization, and only three of those appear to have committed reprehensible acts. The first was involved in illicit currency dealings, while the other two were found guilty of espionage, apparently motivated by personal gain. Only in the first case were the dealings conducted while the person was in the service of the ICRC; the affair ended with his resignation following an internal investigation. In the other two cases, the activities in question took place either before or after the people concerned were employed by the ICRC. All the other allegations stemmed from obvious misunderstanding of the ICRC's mandate and working procedures.

In view of the facts that have now come to light, it appears evident that during the Second World War only a small number of individuals fell prey to influences contrary to the humanitarian ideal.

The text that follows is an updated version of a report by François Bugnion on the current state of investigations undertaken by the ICRC. ${ }^{1}$

1 The initial version was published in IRRC, No. 314, September-October 1996, pp. 562-567. 


\section{The International Committee of the Red Cross infiltrated by the Nazis?}

\section{Update}

Last summer the press published extensive extracts of documents kept in the files of the OSS or Office of Strategic Services (the US intelligence service at the time and predecessor of today's CIA), calling into question the actions of delegates who were working for the International Committee of the Red Cross (ICRC) during the Second World War.

Two kinds of allegation were made:

- protection of German assets and illicit dealings in funds or valuables stolen from victims of Nazi persecution;

- espionage, or even infiltration of the ICRC by agents of Nazi Germany.

The ICRC took these allegations very seriously and immediately started an investigation in order to shed light on them.

Research was conducted in the archives of the ICRC and of the Swiss Federal Political Department (now the Federal Department of Foreign Affairs), and in the files of the Swiss Public Prosecutor's Office.

Steps were also taken to obtain access to the files on former ICRC delegates kept by the French military legal authorities.

There has not yet been enough time to examine all the documents available or to reach any definitive conclusions; on the other hand, we can now add further details to the paper issued by the ICRC on 15 September 1996 and published in the International Review of the Red Cross (No. 314, September-October 1996, pp. 562-567).

\section{Protection of German assets and illicit dealings in looted funds or valuables}

The US documents and research in the archives of the ICRC and the Swiss Confederation show that a former ICRC delegate named Giuseppe Giovanni Beretta was accused of illicit dealings by the Turkish police.

Giuseppe Beretta, a Swiss national from Lugano, was born on 27 October 1900. He emigrated to the US in 1922 and returned to Switzerland via Mexico in 1938. At this stage we have no information on his life during 
those years. The files of the Swiss Public Prosecutor's Office describe him as a tradesman.

On 9 June 1939 Beretta arrived in Zurich, where he stayed until 28 April 1942. During that period he was implicated in two dubious affairs: one involving a notary from Ticino in 1941, and the second relating to false affidavits, for which he was indicted in Zurich a year later.

In connection with the second case Beretta was kept in custody from 27 February to 18 March 1942 . The charges against him were subsequently dropped.

In spite of his record - of which the ICRC was clearly unaware Beretta joined the ICRC on 10 February 1943. There are no details in his personal file of the circumstances of his recruitment. After Beretta had been dismissed, another delegate called Raymond Courvoisier said that his former colleague had been "protected by a friend".

The agreement between the ICRC and Giuseppe Beretta specified inter alia that "Mr Giuseppe Beretta hereby undertakes:

(a) to follow to the letter the instructions that have been or will be given to him by the International Committee of the Red Cross;

(b) [...] to observe the strictest neutrality in both word and deed: to refrain from any acts of a political or religious character and from any activity of a commercial nature, and to bear in mind at all times that he represents the International Committee of the Red Cross".

On 15 February 1943 Beretta left Geneva for Izmir, Turkey, where he arrived on 15 March, after a journey that took him to Budapest, Bucharest, Sofia, Istanbul and Ankara. In Izmir he was put in charge of organizing food supplies for the inhabitants of the Greek Aegean Islands, who were then suffering from a terrible famine. He served as deputy to delegate Raymond Courvoisier, who was based in Ankara.

In August 1943 Beretta was transferred to Istanbul, where his task was to arrange for the transit of relief supplies for Italian prisoners of war in India.

On 12 July 1944 he received news of his mother's death and decided to return to Switzerland, arriving there on 15 July. He left again for Turkey with Raymond Courvoisier on 16 August, but the two men were stranded in Bucharest when the city was taken by the Red Army. Having spent five or six weeks in the Romanian capital, Beretta finally arrived back in Istanbul in late September. While continuing to forward relief supplies for 
Italian prisoners in India, he also took on the task of assisting German nationals interned in Turkey following the break-off of diplomatic relations between the two countries.

In a letter dated 12 December 1944 to Etienne Lardy, the Swiss Minister in Ankara, Professor Herbert Melzig, a stateless person of German origin teaching at the University of Istanbul, denounced two Swiss nationals, Giuseppe Beretta and Richard Gross, who, he said, had helped Max Willy Goetz, a citizen of the Reich living in Turkey under cover of a Hungarian passport but in fact working for the Gestapo, to transport gold and foreign currency from Hungary to Turkey. The gold, he maintained, had been deposited in a safe rented in Beretta's name at the Deutsche Orient Bank in the Galata district of Istanbul. Goetz had then reportedly been expelled to Syria. Professor Melzig stated his intention to inform the Turkish authorities of those dealings.

Professor Melzig's letter reached Etienne Lardy on 18 December 1944. In a confidential telegram to the Swiss Federal Political Department dated 22 December, Lardy summarized the denunciation concerning Giuseppe Beretta, adding that he had just learned "from another source" that Beretta was said to have smuggled a million Romanian lei into Switzerland and then to have had one of his relatives sell them to the ICRC. Moreover, on returning to Turkey, Beretta had reportedly wanted to take with him a large quantity of gold withdrawn from a Swiss bank, but at the very last moment had been persuaded otherwise by a third party. Beretta was also said to have sent gold to Romania in a suitcase with ICRC markings. Minister Lardy suggested that the Federal Political Department inform the ICRC of those allegations, recommending that Giuseppe Beretta be recalled to Switzerland if an emergency investigation should confirm all or part of the facts. He also advised the Department to open all ICRC correspondence arriving in Bern via his legation, as such mail was not checked by his chancellery.

In a letter dated 28 December 1944 and handed over to Frédéric Siordet, Chairman of the ICRC Delegations Commission, the Federal Political Department informed the ICRC of the contents of the telegram it had received from Minister Lardy.

On 4 January 1945, Beretta received the following cable from the ICRC, ordering him to return to Switzerland at once: "Request you to return to Geneva immediately and make your report - stop - please cable scheduled date of departure and proposed itinerary".

Having received no reply from its delegate, the ICRC sent another message on 10 January. 
In a telegram dated 14 January, Beretta informed the ICRC that he intended to leave Ankara for Cairo on 23 January.

The Turkish police pre-empted Beretta's plans, however. Here Beretta's account differs from the version of events given by other sources. Be that as it may, the police conducted a search of his home on 19 January or thereabouts.

As a result, Beretta handed over to the police the 710 gold coins deposited in the safe rented in his name at the Deutsche Orient Bank.

Richard Gross and several of the bank's employees were arrested on Saturday 20 January.

Having obtained permission to leave Turkey, Beretta returned to Ankara on 26 January. The following day he flew to Cairo and then continued on his way to Switzerland, where he arrived on 9 February.

At a meeting attended by Frédéric Siordet and Henri Fauconnier, Director of the Delegations Division, Beretta was informed of the charges against him. He tendered his resignation to the ICRC in writing on 13 February, protesting his innocence and requesting a full investigation of his case. His letter is drafted in terms suggesting that he acted on his own initiative and requested "the International Committee of the Red Cross to accept his resignation from his position as delegate".

On the other hand, in letters dated 13 and 15 March 1945 to Minister Walter Stucki, head of the Federal Political Department's Foreign Affairs Division, Giuseppe Beretta complained that he had been dismissed by the ICRC. That same word is used by the ICRC in other documents. It may therefore be concluded that Beretta was ordered to resign.

Moreover, on 24 January, Jean Pictet, Director-Delegate of the ICRC, had informed Edouard de Haller, Swiss Federal Council Delegate for international aid, that Beretta was on his way back to Geneva and that he would be relieved of his duties "whatever the outcome of the ongoing investigation. The Committee considers it preferable not to keep him in its service, also on account of matters dating back to the time when he was living in Switzerland".

The ICRC had thus learned of Beretta's past history. On 2 February, the federal police authority responsible for aliens residing in Switzerland declared that Beretta was wanted for questioning and tapped his telephone the moment he returned to Switzerland.

Notwithstanding Beretta's resignation, the ICRC organized a meeting on 14 February, bringing Beretta face to face with Frédéric Siordet, Henri 
Fauconnet, Hector Bachmann, Director of the Finance Division, and Théodore Schmidlin of the Federal Political Department's Legal Service.

In the course of the meeting, Beretta admitted to having kept 710 gold coins in a safe-deposit box, but maintained that he had agreed to hold the coins only as a favour to a Hungarian friend by the name of Willy Goetz-Wilmos, a journalist living in Turkey who feared that war would break out between Turkey and Hungary and that his assets would be confiscated. Beretta asserted that the deposit was in no way the product of unlawful trading and that he had readily handed the coins over to the police in exchange for a receipt; there had been no police procedure of any kind, and in particular no search of his home or confrontation. He also maintained that there were no restrictions on gold trading in Turkey.

Beretta categorically denied the other accusations levelled against him and declared that he was the victim of attempted blackmail on the part of Professor Melzig. As regards the alleged transfer of one million lei, Hector Bachmann stated that there was no record of the transaction in the ICRC's accounts.

The minutes of the meeting were signed by each of the participants, who undertook to keep the matter confidential.

The following day, i.e. 15 February, Frédéric Siordet wrote to Edouard de Haller, informing him of the outcome of the meeting. He ended by saying: "Mr B.'s denials are plausible, and have been set down in writing. We must therefore give credence to his statements until further information is available". However, wishing to establish the facts of the matter, Frédéric Siordet asked the Federal Political Department to entrust Minister Lardy with the task of clarifying the following points:

1. Was trading in gold unrestricted in Turkey at the time of the events?

2. Was a search conducted at Beretta's home?

3. Was there a written record of the meeting during which Beretta handed over the coins he was holding?

In a telegram dated 20 February, the Federal Political Department instructed Minister Lardy to investigate those matters.

Frédéric Siordet wrote to Beretta on 22 February 1945 confirming that the ICRC had accepted his resignation. The organization had taken note that the former delegate formally denied the accusations brought against him, but pointed out that agreeing to hold gold in trust was in itself highly imprudent and could even be construed as professional misdemeanour. 
On 26 February Johann Martig, the Swiss Consul in Istanbul, accompanied by Daniel Henri Gagnebin, Attaché at the Swiss Legation, went to see Demir Bey, the Director-General of the Criminal Branch of the Istanbul police, who confirmed that a search had indeed been conducted at Beretta's home and that an investigation was being carried out in relation to the following charges:

1. currency smuggling;

2. export of currency;

3. espionage.

Demir Bey considered "Beretta to be the gang leader" and promised to keep the Swiss Consulate abreast of the results of the investigation.

A letter dated 12 March 1945 (Annex 1) from G. K. Komaktz, Counsellor at the Turkish Legation in Bern, informed the ICRC that Beretta, together with several Turkish and other foreign nationals, were "suspected of contravening the provisions of the law pertaining to the protection of Turkish currency and of importing certain goods without declaring them to customs". The letter makes no mention of the accusation of espionage.

In two long letters dated 13 and 15 March to Walter Stucki, head of the Federal Political Department's Foreign Affairs Division, in which he expresses his discontent about the circumstances of his dismissal from the ICRC, after being subjected to "interrogation by Mr Schmidlin of the FDP in the presence of Mr Siordet, Mr Fauconnet and Mr Bachmann from and at the ICRC", Beretta complained that he had been slandered and issued a torrent of accusations not only against Raymond Courvoisier, but also against several members of the Swiss Legation in Ankara.

Colonel Brigadier Roger Masson, head of Swiss Army Intelligence, intervened on Beretta's behalf in a note dated 23 March 1945, requesting the ICRC to treat the case with "benevolent understanding".

Richard Gross was released on 3 May 1945.

On 8 May Johann Martig and Daniel Gagnebin had a second meeting with Demir Bey. The Swiss Consul's report following the interview stated that the charges levelled against Gross and Beretta were "now limited to illicit currency dealings and smuggling, offences of which Gross and Beretta are equally accused". The Consul added: "When I enquired whether charges of espionage had been brought against the two aforementioned persons as a result of the police investigation, Demir Bey answered in the negative, as the inquiries made in that connection had not yielded any results". 
In a letter dated 4 June 1945, Minister Lardy replied to the accusations that Beretta had directed against him and his staff.

Raymond Courvoisier had meanwhile returned to Switzerland, where he was informed on 3 July that since active hostilities were over in Europe the ICRC "found itself compelled to part with a number of its staff members", among them Courvoisier himself. As the result of an interview with Secretary-General Jean Duchosal, he was offered the post of deputy delegate to the French Armed Forces in Germany. Considering that the proposal was not commensurate with his experience or the services that he had rendered to the institution, Courvoisier resigned from the ICRC on 17 August 1945.

On 30 August, Courvoisier submitted a lengthy aide-mémoire to the ICRC, recounting the whole affair and reiterating his previous accusations against Beretta. The document takes up and expands on the accusations levelled against Beretta by the "other source" to whom Minister Lardy had referred in his telegram of 22 December 1944, leading one to believe that the Minister's informers were Professor Melzig and Raymond Courvoisier, who was Beretta's colleague at the time.

On 13 October 1947 Judge Kemal Bilgin gave his verdict in the proceedings brought against Dimitri Nikolaydis, Riche (sic) Gross, Hiristo Evangelo and Istefan Ivanco Evangelo "on the charge of contravening the provisions of the law pertaining to the protection of Turkish currency". Richard Gross and Hiristo Evangelo were sentenced to three months' imprisonment and a fine of 1,000 Turkish lira, less the time spent in custody awaiting trial, i.e., one day short of three months. The other two defendants were acquitted. No charge was made against Beretta, who was mentioned only once - under the wrongly spelt name of "Dretta" - as having received payment of 3,000 US dollars from one Billi Gütz (sic).

To the best of our knowledge, Beretta was neither charged nor convicted in Switzerland or in Turkey in connection with these events, nor is there any mention of a conviction in the ICRC's files or in the archives of the Swiss Public Prosecutor's Office.

Giuseppe Beretta died in Viganello, Switzerland, on 11 October 1956.

Although it has not been possible to elucidate all aspects of this extremely regrettable affair, a number of conclusions may be drawn: 
1. All the evidence available indicates that the Beretta case was a dubious affair in which the primary motive was personal gain. In spite of his relations with Willy Goetz, nothing suggests that Beretta might have been a German agent or that his sympathies lay with Nazi Germany.

2. Nothing in the files consulted indicates that Beretta might have acted in collusion with someone within the ICRC. His associates, whose names appear regularly in the files, did not belong to the ICRC, and nothing can be deduced from Raymond Courvoisier's allegation that Beretta was recruited under protection from a friend. Indeed, Courvoisier gives no hint of the identity of this friend, who may not have been an ICRC staff member. In addition, Courvoisier's allegation was made after Beretta had tendered his resignation.

3. At the present stage of the investigation, there is no proof that Beretta made wrongful use of the ICRC mail system to transfer funds or valuables to Switzerland. Research carried out by Hector Bachmann, Director of the ICRC's Finance Division, to try and find trace of the million Romanian lei allegedly sold to the ICRC, did not yield any results either. As for the 710 gold coins, they were handed over in Istanbul in January 1945; they had been entrusted to Beretta in May 1944 , and he himself had returned to Switzerland that summer, following his mother's death.

4. The documents in the archives of the ICRC and the Swiss Confederation do not give any indication as to the provenance of the coins entrusted to Beretta's care. The Istanbul newspaper Yeni Sabah of 14 February 1945 maintained that the coins had come from Nazi concentration camps in Austria and Hungary. This is not impossible, but no documents have been found to substantiate that allegation.

5. Colonel Masson's intervention on Beretta's behalf raises the question as to whether Beretta was in fact a member of Swiss Army Intelligence. At this stage, no evidence has been found to that effect. In fact, it appears somewhat unlikely that Beretta was a Swiss intelligence agent, because in that case the most elementary caution would have prevented Colonel Masson from mentioning his name in writing, thus unmasking one of his own agents.

6. It should be noted that the accusations levelled against Beretta and his co-defendants were dropped one after another. The charge of espionage was abandoned rapidly. Possession of gold coins was not an offence in itself, as trading in gold was not subject to restriction in Turkey. At the end of the day, the only remaining charge outstanding 
related to offences against the law protecting Turkish currency - that is, changing money on the black market. When the accused were brought to trial, two of them were acquitted and the other two were sentenced to three months' imprisonment, i.e., the period they had already spent in custody. As the Swiss Minister in Ankara observed at the time, the whole affair just "petered out".

\section{Allegations of espionage}

(a) Other documents in the OSS files call into question the actions of ICRC delegates based in North Africa, and also in Naples and Marseilles.

These allegations are largely based on the confession of Jean-Roger Pagan, a Swiss national who was arrested by the French military security services in Algiers on 14 October 1943 after being caught in the act of spying for German intelligence.

Pagan had been employed by the ICRC from March 1941 to March 1942 in the Colonial Service of the Central Prisoner of War Agency in Geneva, which handled the correspondence of prisoners from the French colonies. He left the ICRC of his own accord in February 1942, stating in his letter of resignation that he was on his way to Morocco, and adding: "Since I shall be returning to Switzerland on business, I could easily represent the Central Prisoner of War Agency in its dealings with French Red Cross organizations in Morocco, Algeria and Tunisia". The ICRC turned down his proposal. In August 1942, Pagan again offered his services to the ICRC, this time to represent it in Dakar, where he said he was also going on business. The ICRC rejected this offer as well.

During interrogation after his arrest, Pagan denounced Georges Graz, the Technical Director of the Central Prisoner of War Agency, who was working in Algiers at the time and who was a former classmate of his. Graz was immediately arrested, on the night of 14 to 15 October 1943, in his room at the Aletti Hotel. During the ensuing search, the military security services confiscated his papers.

Graz, who had been in North Africa since April 1943, was sent there to look into various matters, including the general organization of ICRC delegations in North Africa (Algeria, Morocco and Tunisia); the forwarding to the ICRC of information on prisoners of war and civilian internees in the hands of the French, British and American forces; improvements to the message service between civilians in North Africa and metropolitan 
France and, more generally, the air and ship postal services between Europe and Africa; and repatriation of the seriously wounded.

At the time, the French authorities were holding 55,000 prisoners of war (17,000 Germans and 38,000 Italians) and the British and American forces 210,000 (111,000 Germans and 99,000 Italians).

Georges Graz was very active; he conducted numerous visits to prisoner-of-war camps in difficult conditions (each time travelling two to three thousand kilometres on unpaved roads), to the detriment of his own health. Forced by illness to extend his stay in Algeria by several weeks, he came across his former classmate Pagan, who began to visit him almost daily and performed small services for him, such as typing up his notes.

Graz remained under interrogation until 18 October 1943, when he was released. After a final encounter with Pagan, he left Algiers on 25 October 1943.

Among the documents that were confiscated from his hotel room by the military security services was a copy of a report which Graz had written on his own initiative and which contained his personal impressions on the situation in Morocco, Algeria and Tunisia. The fact that the report underscored the dependence of the Free France authorities on their British and American allies was probably considered an aggravating circumstance.

Convinced of its delegate's entire loyalty, the ICRC responded officially to his arrest in a note dated 3 February 1944 and addressed to the French authorities in Algiers. The answer, dated 29 April 1944, was signed by the Commissioner for Foreign Affairs of the French Committee for National Liberation, Ambassador Massigli. After stating that, owing to the important responsibilities incumbent on them, the services concerned had not been able to overlook, during their investigation, the close private relations between Graz and Pagan at the very time the latter was engaging in criminal activities, the Ambassador wrote:

"These services nevertheless refrained from drawing any conclusions implicating Mr Graz. Indeed, at my request, they authorized him to leave the territory of French North Africa rapidly, for his continued presence would have given rise to difficulties in view of his relationship with the accused.

They thereby intended to show, with the full support of my Commissariat, that all suspicion had been lifted in connection with Mr Graz' activities as a representative of the International Committee of the Red 
Cross. In this respect, I wish formally to renew the assurances which I have already given you."

In the end, no charges were brought against Georges Graz and no legal action was taken against him. This was confirmed in a letter of 7 November 1996 from the officer in charge of the central archives of the French military legal authorities in Le Blanc (Annex 2). Graz may be faulted only for imprudence in having allowed a childhood friend - whom, in fact, he had no reason to mistrust - to visit him when he was sick in bed.

According to the OSS documents - which on this point are invalidated by the aforementioned letter of 7 November 1996 - Pagan implicated other ICRC employees as well, namely, Edouard Wyss-Dunant, Jean Sublet and a certain "Pasch". Pagan was said to have been recruited in Switzerland by Maximilian von Engelbrechten, the Consul in charge of Red Cross affairs at the German Consulate General in Geneva, and by someone named von und zur Mühlen at the German Legation in Bern. His assignment, for which he allegedly received between 10,000 and 20,000 Swiss francs, was to pass on information of an economic and military nature concerning the Allies in French North and West Africa.

As regards Dr Wyss-Dunant, a delegate in Algiers, the ICRC has found no indication whatsoever that he may have engaged in espionage or was accused of doing so.

Jean Sublet, who worked as a volunteer for the ICRC in Tangiers beginning in October 1943, was responsible for forwarding mail from ICRC delegations to Spain and Portugal or North Africa and speeding up the delivery of parcels to both French prisoners of war in Germany and German prisoners of war in North Africa.

It seems that in 1942 he had provided information to the German Consulate in Tangiers about a French prisoner from Germany who had been sentenced to death by a military court in Morocco for his activities in the service of Germany. Thanks to Sublet's intervention, the Frenchman apparently escaped execution and was able to continue his activities against his own country. The ICRC naturally had no knowledge of these events when it took on Sublet, who was at the time an architect in Tangiers and was also involved in the import-export business. When it found out about the accusations against him in late November 1944, the ICRC immediately dismissed Sublet who, although acknowledging the facts, admitted to nothing more than having disclosed confidential information in an ill-considered manner. 
Sublet was blacklisted by the Allies in 1945, but had his name taken off the list a year later as part of a general amnesty.

The OSS documents claim that a certain "Pasch" put Pagan, while the latter was still working for the ICRC, in touch with Maximilian von Engelbrechten. Thus far it has not been possible to identify the person in question. Several people by the name of "Pasche" worked for the ICRC at the time, either as paid staff or as volunteers. However, all were in subordinate posts and none held any important responsibilities.

Von Engelbrechten, the Consul in charge of Red Cross affairs at the German Consulate General, was a contact, not an employee, of the ICRC.

As for Jean-Roger Pagan, he was sentenced to death by a military court in Algiers in September 1944 and executed on 2 December of the same year.

The ICRC has no information indicating that any of the other delegates mentioned in the OSS documents were implicated in this matter or were involved in any espionage activities whatsoever.

(b) The author of the OSS memorandum of 4 February 1944 also calls into question the activities of François Ehrenhold, an ICRC delegate posted in Marseilles, in the following terms:

"Another person in the Red Cross whose activities are dubious is EHRENHOLD, the Swiss German chief of the IRC in Marseilles [...]. According to certain Portuguese reports, however, he makes a practice of interviewing members of the crews of ships which put in at Marseilles and securing naval information through them. It is reported on what we believe to be reliable authority that a certain GUILLENNE CONCALVES COSTA CURTO, chief officer of the Portuguese SS AMBRIZ, transmits information to EHRENHOLD in cigarettes which he takes on shore whenever the ship is in port at Marseilles, and that EHRENHOLD and other Germans ask for CURTO whenever the ship calls there."

In fact, François Ehrenhold was head of a unit dealing with ships flying the Red Cross flag and carrying consignments (relief supplies and correspondence) for prisoners of war. His duties were to supervise the loading of ships so as to ensure that they were not used for purposes other than International Red Cross operations; to allocate the consignments to the various ships; to receive and dispatch cargo; to plan the itineraries (which had to be notified to the warring parties concerned) and forward the necessary instructions to the shipowners or their agents, especially regarding distinctive signs, timetables and routes; to handle formalities with the 
local authorities; and to deal with the staff in charge of supervising the consignments at sea and in the ports of call.

In 1943, the period with which the OSS allegations are concerned, 103 ships hailing from Philadelphia, Buenos Aires and Lisbon called at Marseilles, bringing 110,000 tonnes of relief supplies that were sent on by the delegation to Switzerland aboard 9,400 train cars for dispatch to various prisoner-of-war camps.

The Ambriz, mentioned in the OSS documents, was one of the ships that travelled between Lisbon and Marseilles. On 5 May 1944, it made its 50th voyage under the Red Cross flag.

Thus, it was one of Ehrenhold's regular duties to maintain contact with the ships' crews, in particular the chief officers, and to exchange information with them, above all on security matters.

(c) According to the OSS documents, another delegate came under suspicion because he travelled to Cairo when an important diplomatic conference was taking place there:

"At the time WYSS DUNANT summoned Bon and Kuhne to Algiers, he announced he was sending DUCHOSAL to Cairo. It would not appear that Cairo is an important base for IRC activities, but it is significant that DUCHOSAL was sent there at a time that coincided exactly with the Cairo Conference [...]."

The reason for Jean Duchosal's trip to Cairo is known: he was to try to meet a Soviet diplomat with a view to restoring contact with the authorities of the USSR. Moreover, it was the United States Ambassador in Algiers who, knowing of his assignment, arranged for a plane to take him to Cairo.

Lastly, while the ICRC did occasionally use the United States diplomatic pouch, it was not, as alleged in the OSS documents, in order to evade censorship, but because of the irregularity and slowness of communications which created many difficulties for the Central Prisoner of War Agency. Indeed, it was in the interest of the detaining countries that the information they supplied should reach Geneva - and from there the prisoners' countries of origin - as quickly as possible so that, by the same token, they could receive information about their own detained nationals without delay.

(d) The author of the OSS memorandum of 4 February 1944 confuses Dr Paul Burkhard, an ICRC medical delegate working in Naples, with Professor Carl Burckhardt, a well-known historian and diplomat, former 
High Commissioner of the League of Nations in Danzig, member of the ICRC and Chairman of the Joint Relief Commission of the International Red Cross. It was undoubtedly this confusion that led the author of the memorandum to conclude that the "International Red Cross" had been infiltrated up to the level of its governing bodies, but it also demonstrates the person's meagre knowledge of the ICRC.

(e) The author of the memorandum accuses ICRC delegates, in particular Dr Paul Burkhard, posted in Naples, of having passed on information about the vessel $S$. S. Canada: "Late in December, the IRC headquarters in Geneva cabled IRC in Algiers details of an elaborate communication system for the Red Cross between North Africa and Southern Italy. A Dr BURKHARD was designated as correspondent, and later as co-delegate of IRC for Southern Italy. KUHNE was told to get in touch with him. They were to work in prisoners' camps in Southern Italy. All of this would seem to be legitimate Red Cross activity. In addition, however, the cables set forth plans for an elaborate system of communications and details for the use of a ship, the S. S. CANADA, in terms scarcely necessary, it would appear, for ordinary, or even extraordinary Red Cross use. Inasmuch as KUHNE is already suspect, because of his associates, one inevitably questions the innocence of the plans. Since the date of the first cables, others, of a similar sort, further elaborating the details, have passed." (Memorandum of 4 February 1944, "Enemy agents and the International Red Cross", unsigned, p. 3).

In fact, in a letter dated 24 December 1943, the French Committee for National Liberation in Algiers asked the ICRC to notify the Reich government and the Italian Command of the commissioning of the hospital ship Canada and communicated all its characteristics in accordance with the provisions of Hague Convention No. X of 18 October 1907 (Annex 3). The French government subsequently asked the ICRC to send further notification about the ship on 25 November 1944 (Annex 4).

(f) Likewise, the author of the 21 February 1944 report criticizes Tunis-based delegate Dechevrens for sending a telegram giving the identities and addresses of Corporal Fritz Winkelmann and Corporal Karl Klingemann, both representatives of German prisoners of war. The report continues: "The fact that a German prisoner of war is a trustee in a prison camp seems to be of no possible use for the Red Cross, but distinctly of interest to the German army" (Report dated 21 February 1944, p. 6).

Records show that Corporals Winkelmann and Klingemann acted as representatives of German prisoners of war under Article 43 of the Geneva Convention of 27 July 1929 on the treatment of prisoners of war. It was 
the ICRC's practice to identify prisoner-of-war representatives in its reports; there was nothing confidential about such information.

Moreover, throughout the war the ICRC conveyed the names, addresses and other particulars of several million prisoners of war to both their States of origin and their families. This was done not only for German and Italian prisoners but also for prisoners from Poland, France, Belgium, the Netherlands, Norway, Yugoslavia, Greece, the United Kingdom, the United States, etc. By 1944 one would have had to be particularly ill-informed not to know this.

(g) The other allegations concerning ICRC delegates are largely based on rumour. For example, several delegates are declared to be suspect for the sole reason of having shared rooms with US officers at the Aletti Hotel in Algiers - a circumstance easily explained by the shortage of hotel rooms in a city suddenly promoted to the status of capital of Free France and headquarters of the Allied forces operating in the western Mediterranean.

Similarly, with regard to some delegates, the reports merely mention that they should be placed under surveillance. There is nothing surprising about this, as it is perfectly legitimate for a State at war to monitor the movements of delegates whose task it is to travel widely within the country and abroad, who have access to camps holding enemy prisoners whom they are authorized to interview in private and whose language they might speak, who also have contact with military authorities, whose work often requires them to meet representatives of the enemy along cease-fire lines or in neutral countries, and so forth.

Be that as it may, we have no evidence that the senior American authorities attached to these reports the importance that certain sectors of the media are seeking to ascribe to them today. Neither the US nor the French government withdrew its confidence from the ICRC, nor was the institution asked to recall its delegates.

\section{Conclusions}

US documents published in recent months have named 49 individuals as being suspected by the OSS of engaging in espionage. Of these, 21 are identified as representatives of the "International Red Cross". In fact, 18 were staff members of the ICRC, whether on a permanent or a temporary basis.

At this stage in our investigation, three of these 18 individuals appear to have committed reprehensible acts. 
In one case, a delegate was involved in an affair that bears all the hallmarks of a dubious venture in which the primary motive was personal gain. The ICRC dismissed him as soon as it learned of his activities. Its attempts to shed further light on the matter came to nothing.

As for the two other cases, they did involve espionage, but it should be pointed out that the individuals concerned - who held junior positions - engaged in espionage either after they had left the service of the ICRC or before they began working for it. In any event, the ICRC obviously had no knowledge of such activities.

The allegations regarding the other ICRC delegates are based on rumour and show total ignorance of the organization's role and work. The authors of the reports describe as espionage perfectly normal activities that were conducted openly, with the consent or at the request of the Allied authorities.

Finally, it should be pointed out that during the Second World War the ICRC had over 3,000 employees in Switzerland, mostly working for the Central Prisoner of War Agency and the Relief Division, as many as $\mathbf{1 8 0}$ delegates posted to 92 delegations or sub-delegations in 61 different countries, and several thousand locally recruited employees. By 30 June 1947, the Agency's files contained nearly 36 million index cards. By then the ICRC had received over 59 million letters - mainly requests for information about prisoners of war or other missing persons - and had sent out over 61 million replies. ICRC delegates had made more than 11,170 visits to camps for prisoners of war or civilian internees and had arranged for the delivery and distribution of 470,000 tonnes of relief supplies to prisoners of war and civilian internees - mostly in Germany - or the equivalent of about 90 million 5-kg parcels. The Joint Relief Commission of the International Red Cross had delivered and distributed some 165,000 tonnes of food, medicines and other relief supplies to needy civilians, while over 750,000 tonnes of food and other supplies had been distributed by the ICRC, the Swedish government and the Swedish Red Cross in Greece alone.

Geneva, 28 February 1997

François Bugnion

\section{Annexes}

1. Letter of 12 March 1945 from the Turkish Legation in Bern to the ICRC

2. Letter of 7 November 1996 from the officer in charge of the central archives of the French military legal authorities in Le Blanc, France

3. Letter of 24 December 1943 from the French Committee for National Liberation

4. Letter of 25 November 1944 from the French government 


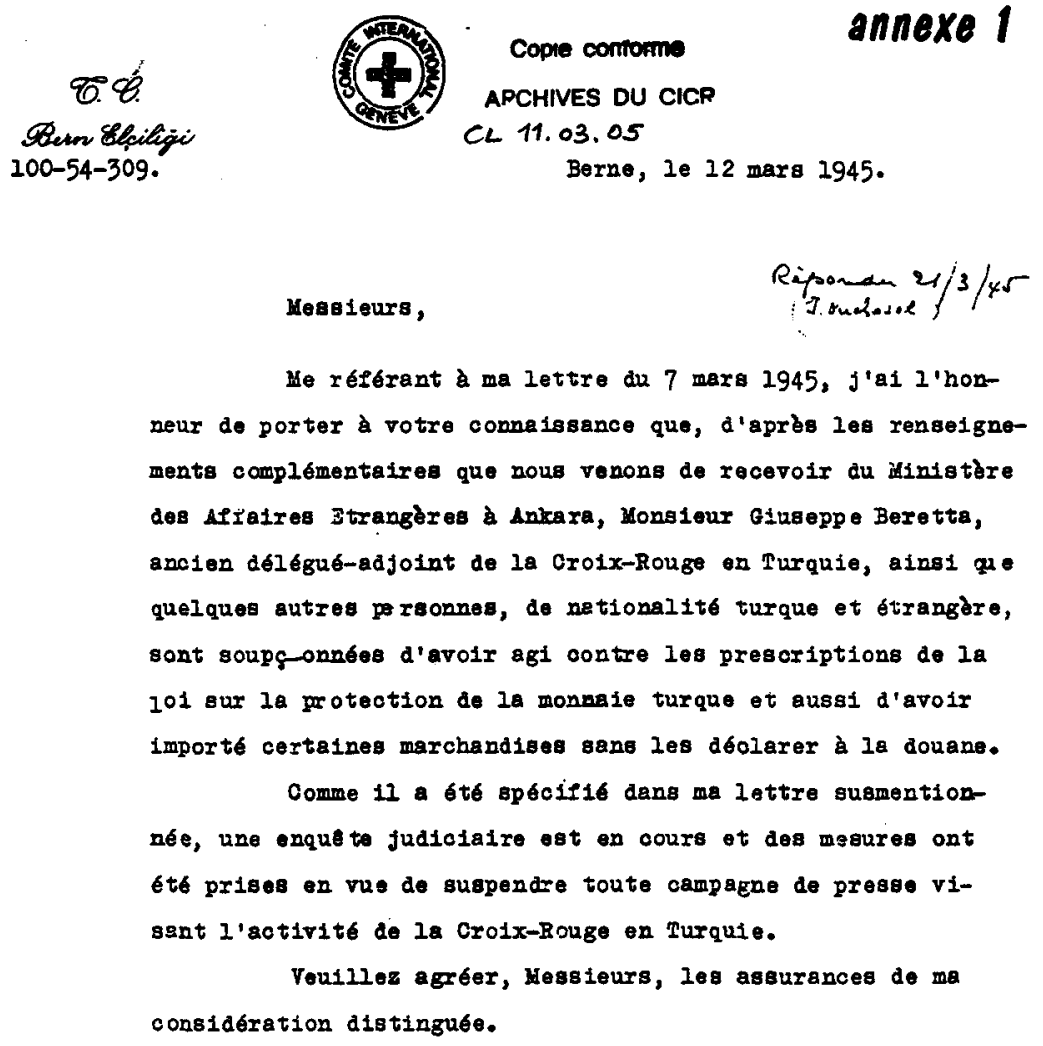

Ie Conseillex de la Iégetion de Turquie:

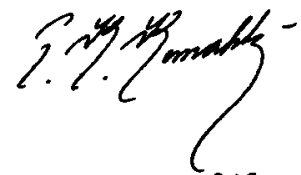

$1350 \times 14$ pinibilig 45

Secrétariat Général du Com1té Internetional

de 1 a Croix-Rouge,

G E I E $Y$ E. 


\section{annexe 2}

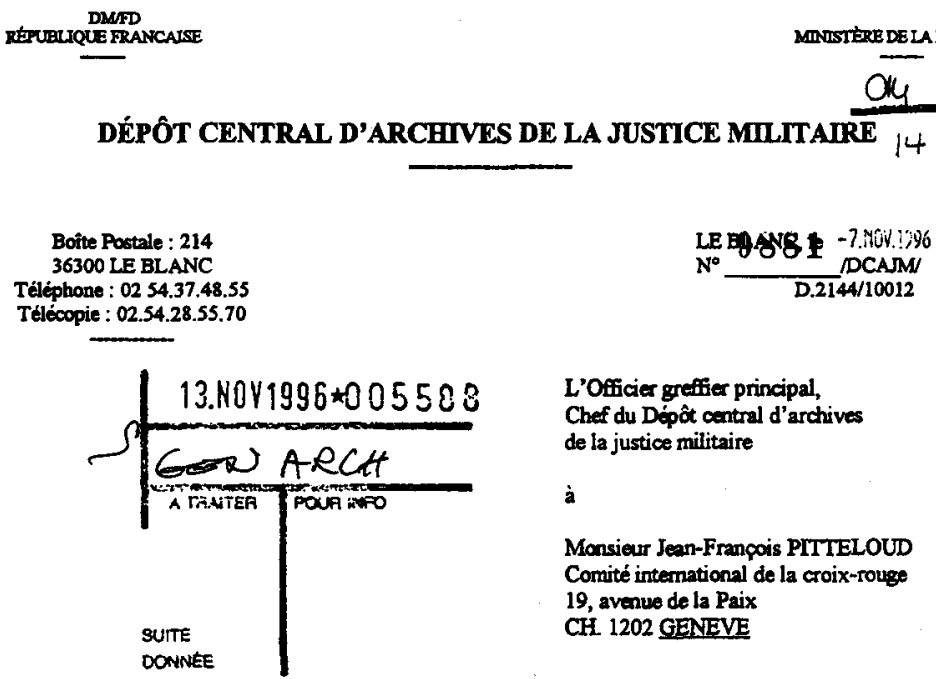

Monsieur,

En réponse à votre lettre en date du 9 octobre 1996, qui m'a été transmise par le Service historique de l'armí de terre, j'ai l'honneur de vous faire connâtre que mon service décient le dossier de la procédure suivie à l'encontre de PAGAN Jean, Roger dovant le Tribunal militaire permanent d'ALGER.

Toutefois, j'ai le regret de vous faire connaître qu'il ne m'est pas possible de donner une suite favorable à votre requête

En effet, s'agissant d'archives judiciaires de la défense, la loi actuellement en vigueur n'autorise pas leur libre consultation avant un délai de cent ans à compter du dernier acte de la procódure.

En outre, d'une part, Monsieur PAGAN n'appartenait plus au Comité international de la croixrouge lors de la commission des faits qui lui sont reprochés ; d'autre part, il résulte de l'ćude du dossier qu'aucun membre du Comité international de la croix-rouge n'a été incriminé par Monsieur PAGAN. Quant à Monsieur GRAZ, il n'a fait l'objet d'aucune poursuite judiciaire.

Je vous prie d'agrér, Monsieur, l'expression de mes salutations distinguées.

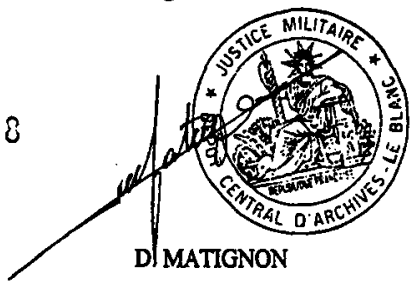




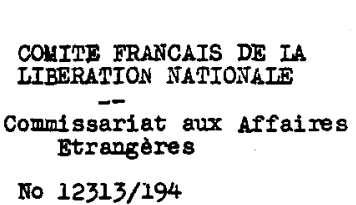

COPIE

Monsieur le Délègué,

$J^{\prime} a i$ I'honneur d'accuser réception de votre lettre No 230 JP.P/MD concermant l'utilisation du "CANADA" comme paquebot hopital.

Me rérérant à la convention de la Haye du 18 octobre 1907 dont les articles II et III stipulent que notification du nom des navires-hopitaux doit etre faite à la Ruissance adverse avant toute mise en usage, je vous serais reconnaissant de prier le Comité International de la Croix Rouge a ceneve de faire cette communication au Gouvrnement du Reich et au Commandement Italien. L'entremise du Comité de Genève parait on effet la voie la plus indiquée pour faire cette communicatioh.

du " CaNaDan.

Je vous indique ci-dessous les caractéristiques

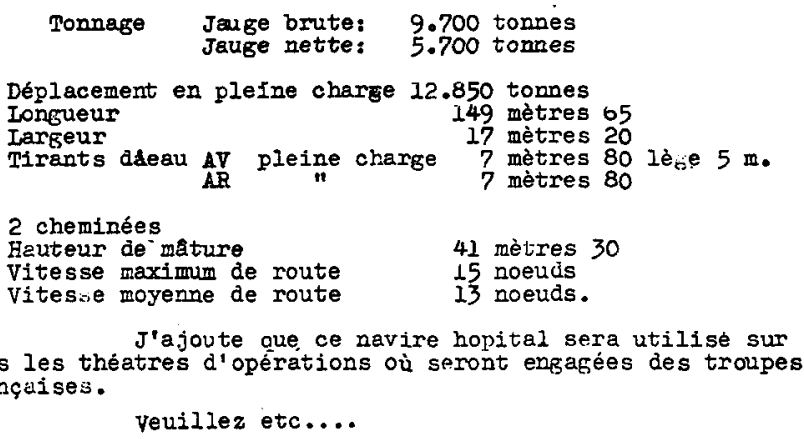

\section{Cople conrorme}

signature

APCHIVES DU CICF

Archives DTCM 


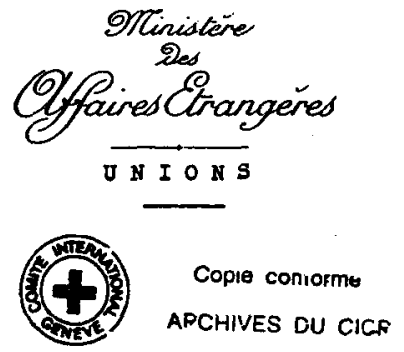

$$
\text { RÉPUBLIQUE FRANÇAISE }
$$

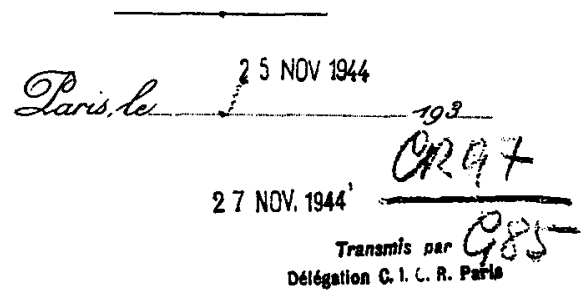

Yonsiour to Dilogut,

Le refrant in in correspondance que mon

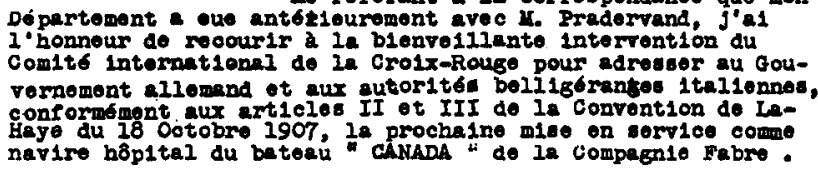

Le Ilofretion du territoire franpaid mftropolitain et 1"Insatallation a Parla du Gouvernement Pro-

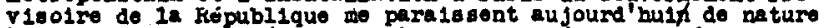
a faciliter cette démarche. Au surplus, ftant donns que lo Com1te International te $1 \mathrm{a}$ Cro1x-rouge joue on France 10 role de protecteur des 1ntér ts allemands, 11 est naturel, que par reclproc1te, le Gouremement allemend a coullile toute action inalogue pour la proteotion dea intertte franga1s, eurtout loreque cotte action se fonde sur une disposition formelle d'une Convention fixant les repports entro belligérents.

caracterintiques du betiment : Jo croil devoli rappeler c1-dessous 203

Tonnege : jauge bruteg.700 tomnes jeuge nette 5.700 tonnes

Deplacement on plo1ne charge 12.850 tonnes

Longuour : 149 in 65

Lurgeur: $17 \mathrm{~m} 20$

Trrant d"onu : AV ple1ne charge 7m.80 lege $5 \mathrm{~m}$. $A R$ : pleine charge $7 m 80$ lege 5 m

2 cheminées

Hautour ntture 41 in 30

Nonslour 10 Docteur de MORSIFR

Delégué du Comlté Intermetronal de la Cro1x-rouge

Ifertion do Sulsso Gronelio - PARIS - 
Vitesse maximum de route : 15 noouds

Vitesse mojenne de route : 13 noekds 2

Le"Canada " sera utilisé au bénefice de la première armée franga1se pour lo transport des bless6s ot malades érecué dos ports méditorranéns sur l'Afrique du NORD.

Je vous prie, Lonsiour le Delśgue, de bien voulolr remerctor 10 Com1té 1ntermational de is Croix-rouge pour son obligeante ontremise et d'agreer l'assurance de ma consideration la plus distinguee.$/$.

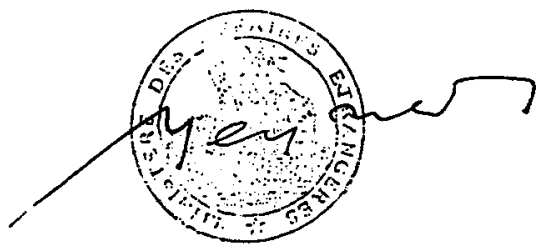

